Int. J. Curr. Res. Med. Sci. (2017). 3(4): 77-79

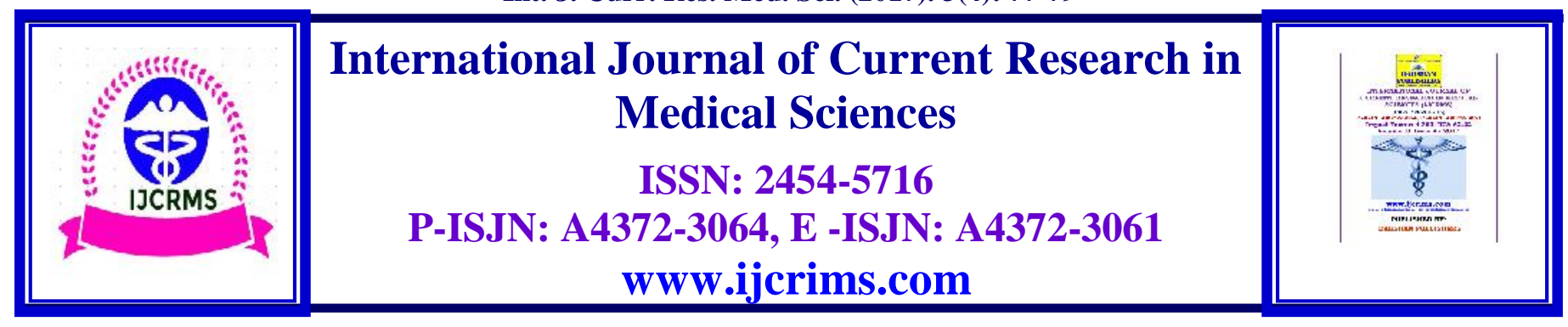

Case Report

Volume 3, Issue 4 -2017

DOI: http://dx.doi.org/10.22192/ijcrms.2017.03.04.012

\title{
Multiple Small Gut diverticula with ilealperforation: A case report
}

Dr. Bhupinder Singh Walia (Assistant Professor, Department of Surgery, Guru Nanak Dev Hospital/Government Medical College, Amritsar)

Dr. Venita Kapur (Professor, Department of Surgery, Guru Nanak Dev Hospital/Government Medical College, Amritsar)

Dr. Kiranjot (Resident, Department of Surgery, Guru Nanak Dev Hospital/Government Medical College, Amritsar)

Dr. Ajay Kumar (Resident, Department of Surgery,

Guru Nanak Dev Hospital/Government Medical College, Amritsar)

Corresponding author: DR. Bhupinder Singh Walia,

Associate Professor of Surgery, Guru Nanak Dev Hospita/ Govt. Medical College, Amritsar, India, 143001

E-mail: bhupindersinghwalia6@gmail.com

\begin{abstract}
Small bowel diverticulosis represents an uncommon pathology that is often misdiagnosed, since it causes non-specific gastrointestinal symptoms. It is defined by the existence of multiple diverticula, which are located most frequently in the jejunum. Acquired and congenital diverticula of the jejunum in the adult are unusual entity. These lesions are usually asymptomatic and may produce chronic symptoms. It is because of the rarity of the entity that they often produce a diagnostic as well as therapeutic dilemma resulting in unnecessary morbidity and mortality. This is a report on a case presented to emergency with features suggestive of perforation peritonitis with incidental finding of multiple small gut diverticula.
\end{abstract}

Keywords: scapula, glenoid cavity, morphology, shoulder arthroplasty.

\section{Introduction}

Diverticulosis of the small intestine is characterized by thepresence of multiple diverticula. Of these, $80 \%$ are found in the jejunum, $15 \%$ in the ileum and $5 \%$ in both $^{1}$.Jejunaldiverticuli are a rare entity and occur in approximately $0.3 \%-1.3 \%$ of the world population ${ }^{2}$.Jejunal diverticulosis may be either congenital or acquired. Its incidence varies from
0.2 to $1.3 \%$ in autopsy studies and $2.3 \%$ in radiographic findings ${ }^{1}$.Small bowel motility disorders with increased intraluminalpressure are considered to be the main etiological factors forits development $^{3}$. They are diagnostic as well as therapeuticchallenge to surgeons throughout the world. Although it is often asymptomatic, it can leadto severe complications including perforation, 
haemorrhage, enterolithformation, diverticulitis and intestinal obstruction ${ }^{4}$.

\section{Case Report}

We report a case of multiplejejunoileal diverticula in a 60 year old male patient presenting with history of fever for 2days and acute abdomen for 1 day. Clinical features were suggestive of perforation peritonitis. Patient was febrile and his physical examination revealed a distended abdomen, no palpable mass per abdomen and mild diffuse tenderness. Per rectal examination

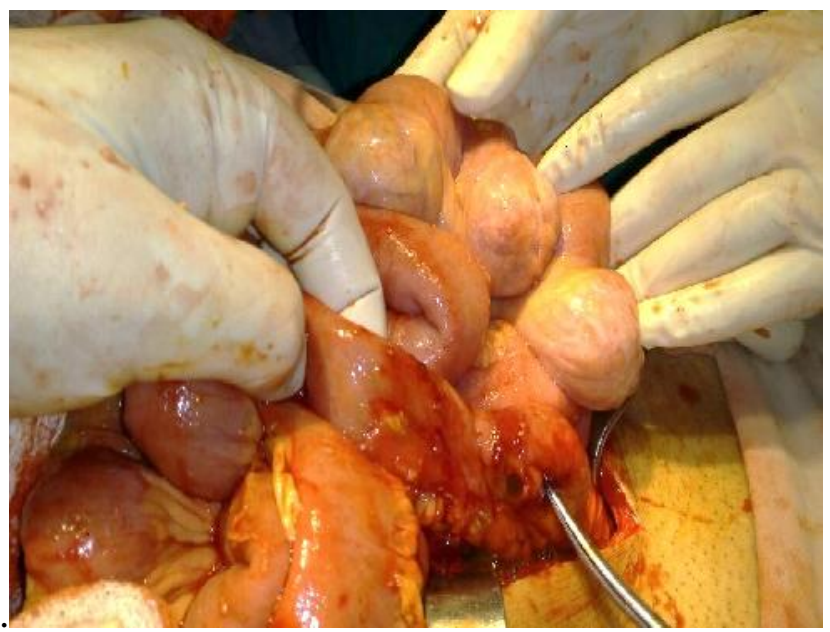

was normal. Abnormal laboratory findings included elevated leukocyte count (14500 cells /cumm). X-ray showed air under diaphragham.

Exploratory laparotomy was done. Intraoperatively we noted the existence of multiple jejunal diverticula on mesenteric border with single ileal diverticula close to ileocaecal junction proximal to which a single ileal perforation was identified. The perforation was repaired with primary closure and peritoneal toilet was performed.

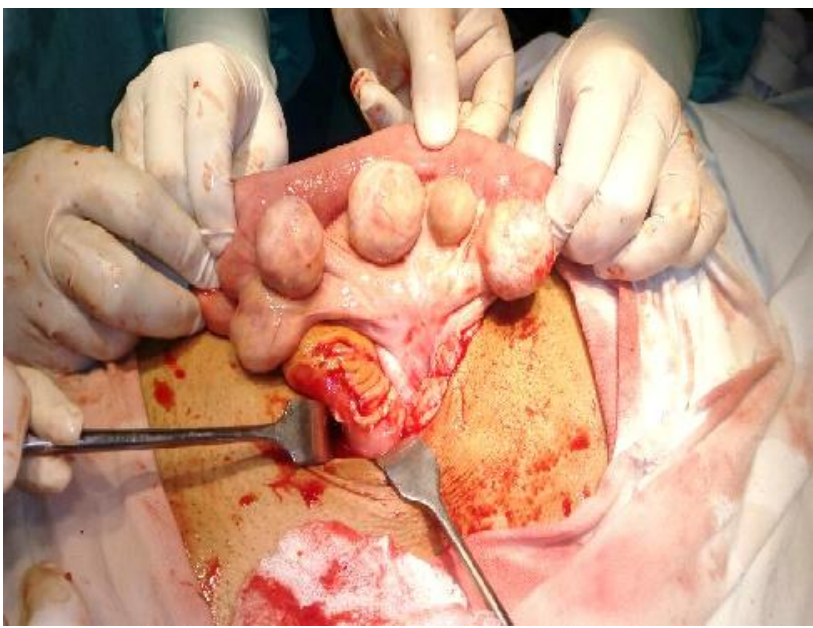

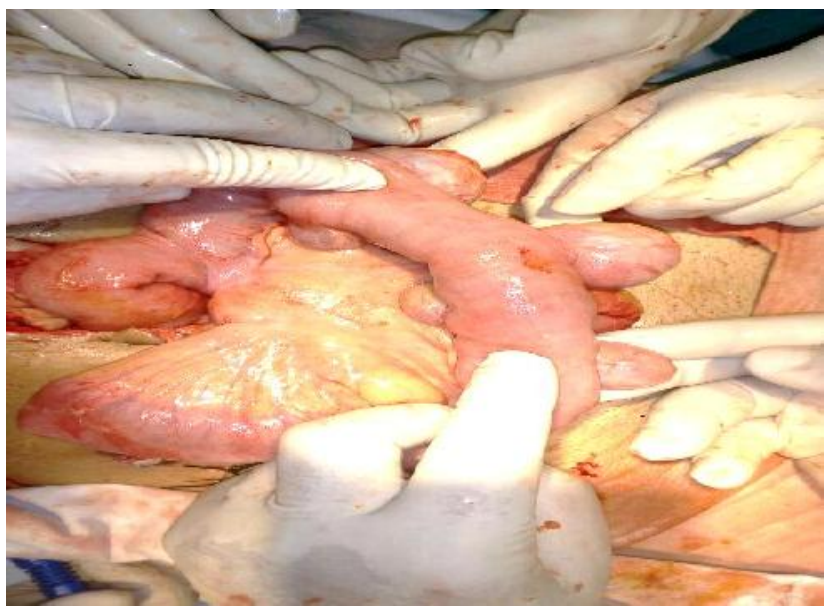

\section{Result}

Post operative period was uneventful. On follow up after 1 month, patient remained symptom free.

\section{Discussion}

Andreas Christ in 1932 reported a rare and unusual disease, namely, diverticulosis of the upper jejunum ${ }^{5}$. Jejunal diverticula are characterized by the herniation of mucosa and submucosa through the muscular layer at the point where blood vessels penetrate the intestinal wall ${ }^{6}$. This explains their typical location at the mesenteric side of the bowel ${ }^{1}$. Diverticula are more frequently found in the jejunum (80\%) than other parts of the small bowel due to the greater diameter of the penetrating jejunalarteries ${ }^{6}$. 
Jejunal diverticula are usually multiple and tend to be larger and in large number in the proximal jejunum $^{6}$.Small bowel diverticula were first described by Soemmering and Baillie ${ }^{7}$. The first instance of jejuna diverticulosis was reported by Sir Astley Cooper ${ }^{8}$. Complications such as obstruction, hemorrhage, diverticulitis and perforation occur in 10\%-30\% of the patients ${ }^{9}$.

\section{Conclusion}

Lateral border of the scapula terminates superiorly at glenoid cavity (GC) which articulates with the head of the humerus to form gleno-humeral joint. ${ }^{1}$ The articular surface of GC is pear shaped, with its inferior half being $20 \%$ larger than the superior half. ${ }^{2}$

\section{Source of funding: Nil}

\section{Conflict of interest: None declared}

\section{References}

1. KassahunWT, Fangmann J, Harms J, Bartels M, Hauss J. Complicated small-bowel diverticulosis: a case report and review of the literature. World J Gastroenterol 2007; 13: $2240-2$.
2. Sager J, Kumar V, Shah DK. Meckels diverticulum; a systematic review. J R Soc Med. 2006;99(10):501-5.

3. Kongara KR, Soffer EE. Intestinal motility in small bowel diverticulosis: a case report and review of the literature. J Clin Gastroenterol 2000;30:84-6.

4. Natarajan K, Phansalkar M, Varghese RG, Thangiah G. Jejunal diverticulosis with perforation - a challenging differential diagnosis of acute abdomen: case report. J Clin Diagn Res2015;9:ED03-ED04.

5. Christ A. Multiple Diverticula of the Jejunum. Langenbecks Arch Surg. 1932;236:560-70.

6. Kouraklis G, Glinavou A, Mantas D, Kouskos E, Karatzas G. Clinical implications of small bowel diverticula. IMAJ2002;4:431-3.

7. Longo WE, Vernava AM: clinical implications of jejunoileal diverticular disease. Dis ColonRectum.1992,35:381-8.

8. Williams R, Davidson DD, Serota AL, Wilson SE. Surgical problems of diverticula of the small bowel. Surg Gynecol Obstet. 1981,152:6.

9. Akhrass R, Yaffe MB, Fischer C, Ponsky J, Shuck JM. Small bowel diverticulosis: perception sandreality. J Am Coll Surg. 1997, 184:383-8.

\begin{tabular}{|c|c|}
\hline \multicolumn{2}{|c|}{ Access this Article in Online } \\
\hline \multirow{2}{*}{ 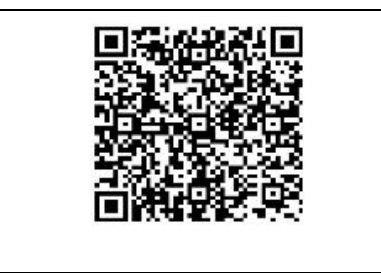 } & $\begin{array}{l}\text { Website: } \\
\text { www.ijcrims.com }\end{array}$ \\
\hline & $\begin{array}{l}\text { Subject: } \\
\text { Medical Sciences }\end{array}$ \\
\hline Quick Response Code & \\
\hline
\end{tabular}

How to cite this article:

Bhupinder Singh Walia, VenitaKapur, Kiranjot, Ajay Kumar (2017). Multiple Small Gut diverticula with ilealperforation: A case report. Int. J. Curr. Res. Med. Sci. 3(4): 77-79.

DOI: http://dx.doi.org/10.22192/ijcrms.2017.03.04.012 